\title{
Income and Employment Generating Activities and Participation Influence of Tank Management Institute Members under KCBTMP
}

\author{
Ashok Doddamani*, B. Krishnamurthy and C. Narayanaswamy \\ Department of Agricultural Extension, University of Agricultural Sciences, \\ GKVK, Bangalore, India \\ *Corresponding author
}

\section{A B S T R A C T}

\section{Keywords \\ Tank systems, \\ Income and \\ Employment \\ Generating \\ Activities \\ Article Info \\ Accepted: \\ 12 December 2020 \\ Available Online: \\ 10 January 2021}

The tank systems have deteriorated to a large extent due to lack of timely repairs and reconstruction. Several interventions has been started to enhance agricultural and horticultural development in the project area. Among these, the demonstration viz., FFS, ACD, WMD and HCD plays a significant role in crop production and productivity significant place. The present study was conducted in Bagepalli taluk of Chikballapur district, Mulbagal taluk of Kolar district, Pavagada taluk of Tumkur district and Chitradurga (Kasaba) taluk of Chitradurga district of Karnataka. The study was conducted with 212 respondents. The result reveled that, the average man days per annum of beneficiaries was increased from 66 days before to 112 days after the rehabilitation of tanks and the average annual income of beneficiaries has increased from Rs. 17,538.18 before to Rs. 37,889.97 after undertaking income generating activity. The on-farm average employment generated per annum has increased from 151.92 before to 246.08 man days after the project. Whereas, off-farm employment generated per annum was increased from 145.42 before and 200.17 man days after the project. The average incremental employment generated (mandays/annum) was 94.16 and 54.75 man days in respect of on-farm and offfarm activities, respectively. The ACD (95.00\%), FFS (93.33\%), WMD (93.33\%) and HCD $(90.63 \%)$ respondents create awareness among their neighbours / friends, while, 93.40 per cent in general created awareness among their neighbours and friends.

\section{Introduction}

There has been a major transformation of farming from the traditional to the modern with millions of farmers, including the small and the marginal, who have become increasingly dependent on science and technology conscious and majority of them participating in the green revolution.
However, it is well known that Agriculture is not only the main source of employment, income and food for over 70 per cent of the population, but it is also the way of life for rural families.

The state is confronted with a development dilemma because, on one hand there is a critical need for rehabilitating the tank systems to the originally designed standards 
to restore the storage capacity, and on the other, the state has been facing increasing resource crunch to take up the required repairs and reconstruction of tank civil structures. Taking the contemporary problems and constraints for efficient management of tanks into account, it was felt that the responsibility of tank management should be handed over back to the communities in future. This process of reinventing the wheel, however, calls for systematic rehabilitation of the entire tank infrastructure before handing over to the community, which obviously calls for huge investment. The tank systems have deteriorated to a large extent due to lack of timely repairs and reconstruction. The government of Karnataka has, therefore, approached the World Bank for assistance to take up the tank rehabilitation programme in the state. In this background, the Karnataka Community Based Tank Management Project (KCBTMP) has been started with the financial assistance from the World Bank.

KCBTMP has started several interventions to enhance agricultural and horticultural development in the project area. Among these, the demonstration viz., FFS, ACD, WMD and HCD plays a significant role in crop production and productivity significant place. These demonstrations have been organized in all the 2000 tanks selected for rehabilitation work in the project districts covering 60,000 farmers and farm women during the project period in a phased manner. The demonstrations has been organized in vegetable, cereal and horticultural crops. The demonstrations were considered as an effective and comprehensive non-formal educational method to teach and technically empower adult farmers and farm women in KCBTMP. The project has been designed for achieving meaningful participation of all stakeholders including vulnerable groups. Tank system is being identified as a common property natural resource and the different user groups are properly identified and an equitable distribution of benefits will be ensured.

\section{Materials and Methods}

The study was conducted in Bagepalli taluk of Chikballapur district, Mulbagal taluk of Kolar district, Pavagada taluk of Tumkur district and Chitradurga (Kasaba) taluk of Chitradurga district of Karnataka. Since Bagepalli and Mulbagalu taluks have more number beneficiaries of On-farm demonstrations on water management (WMD), arable crops (ACD), horticultural crops (HCD) and farmer field school(FFS) were selected for the study while Pavagada and Chitradurga taluks did possess less number of beneficiaries of On-farm demonstrations and FFS were selected to match the respondents. Respondents were selected based on multistage random sampling technique. Sixty beneficiaries from WMD, 60 beneficiaries from ACD and 32 beneficiaries from HCD were selected based on the on-farm demonstrations conducted at the ratio of 2:2:1 (WMD: ACD: HCD) as per the norms of KCBTMPCS and from FFS also 60 beneficiaries were selected. Thus, the study was conducted with 212 respondents wherein each taluk one village for WMD, one village for ACD, one village for HCD and one village for FFS was selected based on the highest number of beneficiaries. From each village 15 respondents was selected through random sampling technique. But, in HCD only 8 respondents was selected, constituting a total sample size of 212 .

\section{Results and Discussion}

A critical analysis of content presented (Table 1) were indicates that, the average man days per annum of beneficiaries was increased from 66 days before to 112 days after the rehabilitation of tanks and the average annual 
income of beneficiaries has increased from Rs. 17,538.18 before to Rs. 37,889.97 after undertaking income generating activity (IGA). The average incremental income secured, employment generated and land unit size was Rs. 20,351.79, 47 man days per annum and 1.73 acre unit size, respectively.

Among various IGA highest average differential annual income was generated from cow + goat rearing (Rs. 45,245.28) with additional 46 man days of employment and 2 numbers of animals followed by milk production enterprise (Rs. 42,570.75) with additional 77 man days of employment and 1 numbers of milk enterprises. This is followed by buffalo rearing (Rs. 32,849.06) with additional 45 man days and 1 numbers of buffalo unit. Further, from fisheries activity average differential annual income, employment generation and additional unit size was Rs. 29,358.49, 40 man days and 0.93 acres, respectively. From goat rearing, average differential annual income was Rs. 26,504.72 with additional 50 man days of employment and average 2 numbers of goats were generated. This was followed by cow rearing (Rs. 25,716.98) with additional 68 man days of employment and 2 cow rearing. From sheep rearing Rs. 24,353.77 annual income was generated with additional 63 man days of employment and 3 number unit size. In case of forage production the average differential annual income was (Rs.17, 169.81) with additional 77 man days and 0.69 acres of unit size. Similarly in case of cow + buffalo rearing the average differential annual income was (Rs. 15,856.13) with additional 41 man days and 1 numbers of cow+ buffalo unit. However, average differential annual income was generated through goat + sheep rearing was Rs. 15,660.38 and additional 57 man days with 1 average differential goat + sheep unit. In case of others: silt, grass, brick making and jungle cutting the average differential annual income was (Rs.
22,429.25) with additional 53 man days of employment. Relatively low benefits were secured in forest nurseries (Rs, 162.74, 2 and 0.49) and foreshore planting (Rs. 2,179.72, 15 and 2.89) with respect to average differential annual income, additional man days and average differential unit size, respectively. With regard to rabbit rearing (Rs. 976.42, 8 and 2) and poultry rearing (Rs. 4,243.40, 51 and 5) were seen with respect to average differential annual income, additional man days and average differential numbers of animals.

Cow, buffalo and goat rearing is traditionally practiced in the villages and it is convenient for them. Under the project cow, buffalo and goat/sheep were distributed free of cost to the selected TMI members. As a result, majority of TMI members were undertaken such type of activities. With the effect of tank rehabilitation the study area is also having more irrigated land by which they could get sufficient fodder for animals all round the year. Majority of cow rearing beneficiaries were found in all villages. In these villages the SHG members have also established cooperative milk collection centers. These reasons might have contributed to rear cows by more number of beneficiaries in the tank command area. Most of the landless beneficiaries had undertaken goat and sheep rearing due to CBTMPCS had given one sheep and goat free of cost to selected TMI member and establishment of more number of water points and check dams in the study area under KCBTMP project activities. The another reason for that, those who possessed land went for cow rearing, buffalo rearing and cow + buffalo rearing and those who did not possess any land, resorted to sheep rearing, goat rearing, sheep + goat rearing, buffalo + goat rearing and kirani shop. It implies that, KCBTMP project had encouraged the appropriate income generating activities based on their resources and their interest, 
ability to manage and also motivation level.

Among all income generating activities highest annual incremental income was generated by cow rearing because beneficiaries were rearing high milk yielding cross breed cows and also had cooperative milk collection centers at villages through which they could able to get good prices for milk produced. Thus, as compared to beneficiaries who have undertaken other income generating activities, cow rearing beneficiaries were getting high annual incremental income. These reasons might have contributed to generate more income by cow rearing beneficiaries.

Further, other income generating activities such as buffalo rearing, sheep rearing, goat rearing and kirani shop have also generated considerably higher income when compared to income earned by their earlier livelihood practices. The results are in line with the study conducted by Puhazhendi (2000), Jayachandra and Gurappa Naidu (2006), Mavi et al., (2006), Hari and Kumawat (2006), Arun Kumar (2004), Dasaratharamaiah (2006) and Biradar (2008).

As stated by the respondents the highest additional 106.45 (on-farm) and 82.00 (offfarm) man days employment generated from ACD activity followed by WMD respondents who generated 93.40 (on-farm) and 44.30 (off-farm) man days employment (Table 2). As per the HCD respondents 87.28 (on-farm) and 35.44 (off-farm) additional man days employment generated annually. Further, as reported by FFS respondents 86.30 (on-farm) and 48.25 (off-farm) additional man days employment generated annually.

In general, the average on-farm employment generated per annum has increased from 151.92 before to 246.08 man days after the project. Whereas, off-farm employment generated per annum was increased from 145.42 before and 200.17 man days after the project. The average incremental employment generated (mandays/annum) was 94.16 and 54.75 man days in respect of on-farm and offfarm activities, respectively.

The tank rehabilitation work leads to increase the water storage capacity and tanks were filled with water even in summer season. For this reason, many of the command area farmers undertaken one or the other agricultural and allied activities which supported them to generate more employment opportunities in the village. The another reason was that, several new agricultural technologies introduced by CBTMPCS staff had more impact in increasing crop yields and income. These factors created interest among the farmers after the project which helped them in generating employment opportunities. One of the reasons for generation of additional mandays with respect to certain beneficiaries was that the alternative employment opportunities availed to them. The findings are in line with the Hari and Kumawat (2006), Kenchanagoudar (2007) and Biradar (2008).

A great majority of the $(78.13 \%) \mathrm{HCD}$, (65.00\%) ACD and (61.67\%) WMD respondents were fully influenced by extension interventions of on-farm demonstrations followed by partial influence of on-farm demonstrations on ACD (28.33\%), WMD (26.67\%) and HCD (21.88\%) respondents (Table-3). Whereas 46.67 per cent and 31.67 per cent of the FFS respondents were not influenced and fully influenced by extension interventions of onfarm demonstrations, respectively.

In general, 56.60 per cent of the respondents were fully influenced by on-farm demonstration whereas, 18.40 per cent respondents were not influenced by the same 
extension interventions. More number of famers were fully influenced by on-farm demonstration as the, demonstration were conducted in the presence of farmers to show the worth of new technologies and as such they were convinced about the new interventions.

A majority of the FFS respondents $(75.00 \%)$ had full influence of farmers field schools extension interventions followed by HCD (40.63\%), WMD (33.33\%) and ACD $(30.00 \%)$ per cent of the respondents, respectively. Equal number of respondents (21.67\%) had partial influence of farmers field school extension interventions on WMD and ACD respondents whereas, only 18.75 per cent and 6.67 per cent of the HCD and FFS respondents had partial influence of farmers field schools extension interventions. The overall response from the respondents to full influence of farmers field schools extension intervention was 45.28 per cent followed by 16.98 per cent partial influence. For getting full influenced of farmers the reason might be that while conducting FFS activity the participating farmers receive on the spot technical guidance from the qualified field extension staff in 6-8 session conducted during the crop period.

The other reason may be that, inter personal communication was quite strong in FFS. Therefore, acquisition and retention of knowledge on the subjects transferred during FFS was quite strong among respondents. Also, the agriculture enterprise involves complex practices requiring adequate skills to practice in field situations and this calls for intimate, continuous and face to face guidance, which might have resulted in the present findings.

In case of influence of STV members training-EDP, more number of respondents were partial influence on FFS (56.67\%), HCD
$(50.00 \%)$ and WMD (40.00\%) respondents whereas a good number of ACD respondents $(38.33 \%)$ did not have influence of STV members training-EDP on TMI members. The respondents fully influenced by STV members training EDP on TMI members were 18.75 per cent, 26.67 per cent and 28.33 per cent form HCD, WMD and ACD respectively. The overall response regarding influence of STV members training - EDP was 44.34 per cent partial, 28.30 per cent no influence and 27.36 per cent full influence on the TMI members. The various types of trainings were conducted on entrepreneurship development programme like, dairy, fishery, poultry, rabbit, goat and sheep rearing and piggery rearing as an alternate enterprise for improving the socio-economic status of farmers was influenced the STV members partially.

More number of respondents had partial influence in respect of STV member trainingSDP from FFS (55.50\%) and HCD (40.63\%) activity. In case of ACD and WMD respondents, 46.67 per cent and 38.33 per cent did not have influence of STV members training-SDP. Only, 15.00 per cent, 25.00 per cent and 28.13 per cent of the ACD, WMD and HCD respondents had full influence on STV members training - SDP, respectively. Overall expressions of the respondents were, 42.92 per cent had partial influence of STV members training - SDP on TMI members followed by none 33.96 per cent and full influence 23.11 per cent. For this response the reasons might be that the STV members training -SDP involves more of practical skills teaching during the training period. Probably, the farmers who underwent STV members-SDP training might not have received more opportunities for skill teaching during the period of training. Hence, there was much influence of SDP training on respondents. 
Table.1 Support of Income generating activities under KCBTMP to tank management institution members N=212

\begin{tabular}{|c|c|c|c|c|c|c|c|c|c|c|}
\hline \multirow[t]{2}{*}{$\begin{array}{l}\text { SI. } \\
\text { No. }\end{array}$} & \multirow{2}{*}{$\begin{array}{c}\text { Income } \\
\text { generating } \\
\text { activities }\end{array}$} & \multicolumn{2}{|c|}{$\begin{array}{l}\text { Average man } \\
\text { days/ annum }\end{array}$} & \multirow[t]{2}{*}{$\begin{array}{c}\text { Additional man } \\
\text { days/annum }\end{array}$} & \multicolumn{2}{|c|}{$\begin{array}{c}\text { Average annual income } \\
\text { (Rs.) }\end{array}$} & \multirow{2}{*}{$\begin{array}{c}\text { Average } \\
\text { differential } \\
\text { annual income } \\
\text { (Rs.) }\end{array}$} & \multicolumn{2}{|c|}{$\begin{array}{l}\text { Average unit size } \\
\text { /No }\end{array}$} & \multirow{2}{*}{$\begin{array}{c}\text { Average } \\
\text { differential of } \\
\text { unit size / No }\end{array}$} \\
\hline & & Before & After & & Before & After & & Before & After & \\
\hline 1 & $\begin{array}{l}\text { Forage production } \\
\text { (ac) }\end{array}$ & 114 & 191 & 77 & 21471.70 & 38641.51 & 17169.81 & 0.85 & 1.54 & 0.69 \\
\hline 2 & $\begin{array}{l}\text { Milk production } \\
\text { enterprise (no) }\end{array}$ & 52 & 129 & 77 & 17415.09 & 59985.85 & 42570.75 & 1 & 2 & 1 \\
\hline 3 & $\begin{array}{l}\text { Foreshore Planting } \\
\text { (ac) }\end{array}$ & 0.00 & 15 & 15 & 0.00 & 2179.72 & 2179.72 & 0.00 & 2.89 & 2.89 \\
\hline 4 & $\begin{array}{l}\text { Forest Nurseries } \\
\text { (ac) }\end{array}$ & 0.00 & 2 & 2 & 0.00 & 162.74 & 162.74 & 0.00 & 0.49 & 0.49 \\
\hline 5 & Fisheries(ac) & 26 & 66 & 40 & 10688.68 & 40047.17 & 29358.49 & 0.25 & 1.18 & 0.93 \\
\hline 6 & Cow rearing (no) & 94 & 162 & 68 & 21433.96 & 47150.94 & 25716.98 & 1 & 3 & 2 \\
\hline 7 & $\begin{array}{l}\text { Buffalo rearing } \\
\text { (no) }\end{array}$ & 123 & 168 & 45 & 33622.64 & 66471.70 & 32849.06 & 1 & 2 & 1 \\
\hline 8 & $\begin{array}{l}\text { Cow+ Buffalo } \\
\text { rearing (no) }\end{array}$ & 85 & 126 & 41 & 18339.62 & 34195.75 & 15856.13 & 1 & 2 & 1 \\
\hline 9 & $\begin{array}{l}\text { Buffalo + Goat } \\
\text { rearing (no) }\end{array}$ & 70 & 116 & 46 & 25811.32 & 71056.60 & 45245.28 & 2 & 5 & 3 \\
\hline 10 & Sheep rearing (no) & 81 & 144 & 63 & 24018.87 & 48372.64 & 24353.77 & 2.00 & 5 & 3 \\
\hline 11 & Goat rearing (no) & 103 & 153 & 50 & 23080.19 & 49584.91 & 26504.72 & 2 & 4 & 2 \\
\hline 12 & $\begin{array}{l}\text { Goat+ Sheep } \\
\text { rearing (no) }\end{array}$ & 86 & 145 & 57 & 26287.74 & 41948.11 & 15660.38 & 2 & 3 & 1 \\
\hline 13 & Poultry (no) & 57 & 108 & 51 & 2652.83 & 6896.23 & 4243.40 & 3 & 7 & 5 \\
\hline 14 & Rabbits (no) & 0.00 & 8 & 8 & 0.00 & 976.42 & 976.42 & 0.00 & 2 & 2 \\
\hline \multirow[t]{3}{*}{15} & $\begin{array}{l}\text { Other: silt, Grass, } \\
\text { Brick making and } \\
\text { Jungle cutting }\end{array}$ & 92 & 145 & 53 & 38250.00 & 60679.25 & 22429.25 & 0.00 & 0.00 & 0.00 \\
\hline & Total & 983 & 1678 & 698 & 263072.64 & 568349.53 & 305276.89 & 16.1 & 41.1 & 26 \\
\hline & Average & 66 & 112 & 47 & 17538.18 & 37889.97 & 20351.79 & 1.07 & 2.74 & 1.73 \\
\hline
\end{tabular}


Table.2 Employment Generation (Man days per Annum) Under the KCBTMP N=212

\begin{tabular}{|c|c|c|c|c|c|}
\hline \multirow[t]{2}{*}{ Sl. No. } & \multirow[t]{2}{*}{ Respondents } & \multirow[t]{2}{*}{ Nature of employment } & \multicolumn{2}{|c|}{ Average man days/annum } & \multirow[t]{2}{*}{ Additional man days/annum } \\
\hline & & & Before & After & \\
\hline \multirow[t]{2}{*}{1} & \multirow[t]{2}{*}{ FFS $\left(n_{1}=60\right)$} & On-farm employment & 180 & 266 & 86 \\
\hline & & Off-farm employment & 115 & 164 & 49 \\
\hline \multirow[t]{2}{*}{2} & \multirow[t]{2}{*}{ WMD $\left(n_{2}=60\right)$} & On-farm employment & 130 & 223 & 93 \\
\hline & & Off-farm employment & 166 & 210 & 44 \\
\hline \multirow[t]{2}{*}{3} & \multirow[t]{2}{*}{$\operatorname{ACD}\left(n_{3}=60\right)$} & On-farm employment & 144 & 251 & 107 \\
\hline & & Off-farm employment & 142 & 224 & 82 \\
\hline \multirow[t]{2}{*}{4} & \multirow[t]{2}{*}{$\operatorname{HCD}\left(n_{4}=60\right)$} & On-farm employment & 156 & 243 & 87 \\
\hline & & Off-farm employment & 169 & 204 & 35 \\
\hline \multirow[t]{2}{*}{5} & \multirow[t]{2}{*}{ Total $(n=212)$} & On-farm employment & 152 & 246 & 94 \\
\hline & & Off-farm employment & 145 & 200 & 55 \\
\hline
\end{tabular}

Table.3 Influence of extension interventions on extent of participation of TMI members under KCBTMP

\begin{tabular}{|c|c|c|c|c|c|c|c|c|c|c|c|c|}
\hline \multirow[t]{2}{*}{$\begin{array}{l}\text { Sl. } \\
\text { No. }\end{array}$} & \multirow[t]{2}{*}{ Extension Interventions } & \multirow[t]{2}{*}{ Categories } & \multicolumn{2}{|c|}{$\begin{array}{l}\text { Influence of FFS } \\
\qquad\left(n_{1}=60\right)\end{array}$} & \multicolumn{2}{|c|}{$\begin{array}{l}\text { Influence of WMD } \\
\qquad\left(\mathbf{n}_{2}=60\right)\end{array}$} & \multicolumn{2}{|c|}{$\begin{array}{l}\text { Influence of ACD } \\
\qquad\left(n_{3}=60\right)\end{array}$} & \multicolumn{2}{|c|}{$\begin{array}{l}\text { Influence of HCD } \\
\qquad\left(n_{4}=60\right)\end{array}$} & \multicolumn{2}{|c|}{ Overall $(n=212)$} \\
\hline & & & No. & $\%$ & No. & $\%$ & No. & $\%$ & No. & $\%$ & No. & $\%$ \\
\hline \multirow[t]{3}{*}{1} & \multirow{3}{*}{$\begin{array}{l}\text { On-farm } \\
\text { demonstrations }\end{array}$} & Full & 19 & 31.67 & 37 & 61.67 & 39 & 65.00 & 25 & 78.13 & 120 & 56.60 \\
\hline & & Partial & 13 & 21.67 & 16 & 26.67 & 17 & 28.33 & 7 & 21.88 & 53 & 25.00 \\
\hline & & None & 28 & 46.67 & 7 & 11.67 & 4 & 6.67 & 0 & 0.00 & 39 & 18.40 \\
\hline \multirow[t]{3}{*}{2} & \multirow[t]{3}{*}{ Farmer field Schools } & Full & 45 & 75.00 & 20 & 33.33 & 18 & 30.00 & 13 & 40.63 & 96 & 45.28 \\
\hline & & Partial & 4 & 6.67 & 13 & 21.67 & 13 & 21.67 & 6 & 18.75 & 36 & 16.98 \\
\hline & & None & 11 & 18.33 & 27 & 45.00 & 29 & 48.33 & 13 & 40.63 & 80 & 37.74 \\
\hline \multirow[t]{3}{*}{3} & \multirow{3}{*}{$\begin{array}{l}\text { STV Members Training } \\
\text { - EDP }\end{array}$} & Full & 19 & 31.67 & 16 & 26.67 & 17 & 28.33 & 6 & 18.75 & 58 & 27.36 \\
\hline & & Partial & 34 & 56.67 & 24 & 40.00 & 20 & 33.33 & 16 & 50.00 & 94 & 44.34 \\
\hline & & None & 7 & 11.67 & 20 & 33.33 & 23 & 38.33 & 10 & 31.25 & 60 & 28.30 \\
\hline \multirow[t]{3}{*}{4} & \multirow{3}{*}{$\begin{array}{l}\text { STV Members Training } \\
\text { - SDP }\end{array}$} & Full & 16 & 26.67 & 15 & 25.00 & 9 & 15.00 & 9 & 28.13 & 49 & 23.11 \\
\hline & & Partial & 33 & 55.00 & 22 & 36.67 & 23 & 38.33 & 13 & 40.63 & 91 & 42.92 \\
\hline & & None & 11 & 18.33 & 23 & 38.33 & 28 & 46.67 & 10 & 31.25 & 72 & 33.96 \\
\hline \multirow[t]{3}{*}{5} & \multirow[t]{3}{*}{ Study Tour } & Full & 25 & 41.67 & 39 & 65.00 & 37 & 61.67 & 19 & 59.38 & 120 & 56.60 \\
\hline & & Partial & 20 & 33.33 & 14 & 23.33 & 19 & 31.67 & 10 & 31.25 & 63 & 29.72 \\
\hline & & None & 15 & 25.00 & 7 & 11.67 & 4 & 6.67 & 3 & 9.38 & 29 & 13.68 \\
\hline
\end{tabular}


Table.4 Extent of influence of demonstration farmers of the project on their fellow farmers

\begin{tabular}{|c|c|c|c|c|c|c|c|c|c|c|c|c|}
\hline \multirow{3}{*}{$\begin{array}{l}\text { Sl. } \\
\text { No. }\end{array}$} & \multirow[t]{3}{*}{ Item } & & \multicolumn{8}{|c|}{ Influence } & \multirow{2}{*}{\multicolumn{2}{|c|}{$\begin{array}{c}\text { Total } \\
(\mathbf{n}=212)\end{array}$}} \\
\hline & & & \multicolumn{2}{|c|}{ FFS $\left(n_{1}=60\right)$} & \multicolumn{2}{|c|}{$\mathrm{WMD}\left(\mathbf{n}_{2}=60\right)$} & \multicolumn{2}{|c|}{$\begin{array}{c}\mathrm{ACD} \\
\left(\mathbf{n}_{3}=60\right)\end{array}$} & \multicolumn{2}{|c|}{$\begin{array}{c}\text { HCD } \\
\left(\mathbf{n}_{4}=32\right)\end{array}$} & & \\
\hline & & & Yes & No & Yes & No & Yes & No & Yes & No & Yes & No \\
\hline \multirow[t]{2}{*}{1} & \multirow{2}{*}{$\begin{array}{l}\text { Did you create any awareness among neighbors'/ } \\
\text { friends? }\end{array}$} & No. & 56 & 4 & 56 & 4 & 57 & 3 & 29 & 3 & 198 & 14 \\
\hline & & $\%$ & 93.33 & 6.67 & 93.33 & 6.67 & 95.00 & 5.00 & 90.63 & 9.38 & 93.40 & 6.60 \\
\hline \multirow[t]{2}{*}{2} & \multirow{2}{*}{$\begin{array}{l}\text { Did any farmer/farmwomen seek technical } \\
\text { information from you? }\end{array}$} & No. & 51 & 9 & 41 & 19 & 54 & 6 & 26 & 6 & 172 & 40 \\
\hline & & $\%$ & 85.00 & 15.00 & 68.33 & 31.67 & 90.00 & 10.00 & 81.25 & 18.75 & 81.13 & 18.87 \\
\hline \multirow[t]{2}{*}{3} & \multirow{2}{*}{$\begin{array}{l}\text { Whether they have adopted the technical } \\
\text { information you provided to them? }\end{array}$} & No. & 36 & 24 & 32 & 28 & 33 & 27 & 18 & 14 & 119 & 93 \\
\hline & & $\%$ & 60.00 & 40.00 & 53.33 & 46.67 & 55.00 & 45.00 & 56.25 & 43.75 & 56.13 & 43.87 \\
\hline \multirow[t]{16}{*}{4} & $\begin{array}{l}\text { i. Mention the type of technological } \\
\text { intervention? }\end{array}$ & & & & & & & & & & & \\
\hline & \multirow{2}{*}{$\begin{array}{l}\text { a. ICM with IPM and INM (Integrated Crop } \\
\text { Management) }\end{array}$} & No. & 28 & 32 & 36 & 24 & 34 & 26 & 21 & 11 & 119 & 93 \\
\hline & & $\%$ & 46.67 & 53.33 & 60.00 & 40.00 & 56.67 & 43.33 & 65.63 & 34.38 & 56.13 & 43.87 \\
\hline & \multirow{2}{*}{$\begin{array}{l}\text { b. INM alone (Integrated Nutrient } \\
\text { Management) }\end{array}$} & No. & 27 & 33 & 27 & 33 & 26 & 34 & 17 & 15 & 97 & 115 \\
\hline & & $\%$ & 45.00 & 55.00 & 45.00 & 55.00 & 43.33 & 56.67 & 53.13 & 46.88 & 45.75 & 54.25 \\
\hline & \multirow[t]{2}{*}{ c. IPM alone (Integrated Pest Management) } & No. & 35 & 25 & 26 & 34 & 28 & 32 & 15 & 17 & 104 & 108 \\
\hline & & $\%$ & 58.33 & 41.67 & 43.33 & 56.67 & 46.67 & 53.33 & 46.88 & 53.13 & 49.06 & 50.94 \\
\hline & \multirow[t]{2}{*}{ d. IWM (Integrated Water Management) } & No. & 37 & 23 & 40 & 20 & 31 & 29 & 19 & 13 & 127 & 85 \\
\hline & & $\%$ & 61.67 & 38.33 & 66.67 & 33.33 & 51.67 & 48.33 & 59.38 & 40.63 & 59.91 & 40.09 \\
\hline & ii. What is the extent of adoption? & & & & & & & & & & & \\
\hline & \multirow[t]{2}{*}{ a. Full adoption } & No. & 24 & & 21 & & 22 & & 11 & & 78 & \\
\hline & & $\%$ & 40.00 & & 35.00 & & 36.67 & & 34.38 & & 36.79 & \\
\hline & \multirow[t]{2}{*}{ b. Partial adoption } & No. & 31 & & 29 & & 34 & & 17 & & 111 & \\
\hline & & $\%$ & 51.67 & & 48.33 & & 56.67 & & 53.13 & & 52.36 & \\
\hline & \multirow[t]{2}{*}{ c. Non adoption } & No. & 5 & & 10 & & 4 & & 4 & & 23 & \\
\hline & & $\%$ & 8.33 & & 16.67 & & 6.67 & & 12.50 & & 10.85 & \\
\hline
\end{tabular}

No. - Number $\quad \%$ - Per cent Management Demonstration

ACD- Arable Crop Demonstration
FFS - Farmer Field Schools $\quad$ WMD - Water

HCD - Horticultural Crop Demonstration 
In respect of study tours full influence was seen among the respondents of WMD, ACD, HCD and FFS with 65.00 per cent, 61.67 per cent, 59.38 per cent and 41.67 per cent, respectively. Only a few respondents had no influence of study tour. Less response with 6.67 per cent, 9.38 per cent, 11.67 per cent and 25.00 per cent was found with respect to ACD, HCD, WMD and FFS respondents, respectively. In general a majority $(56.60 \%)$ of the respondents had full influence from study tours followed by partial $(29.77 \%)$ and none $(13.68 \%)$ influence of study tours. Further study tour were fully influenced majority of farmers as these study tours exposed there to live situation of latest technical interventions either at the agricultural research stations or progressive farmers fields which enable to develop confidence about the new technologies with critical observations and interactions with demonstrations. Hence, study tours exert strong influence on the respondents. The findings are in line with the Shashidhar (2004).

It can be observed that ACD (95.00\%), FFS (93.33\%), WMD (93.33\%) and HCD $(90.63 \%)$ respondents create awareness among their neighbours / friends, while, 93.40 per cent in general created awareness among their neighbours and friends (Table-4). About 90.00 per cent of other farmers have sought technical information from the ACD respondents, followed by 85.00 per cent, 81.25 per cent and 68.38 per cent of other farmers obtained technical information with respect to FFS, HCD and WMD respondents, respectively and overall it was seen 81.13 per cent. Whereas, 60.00 per cent (FFS), 56.25 per cent (HCD), 55.00 per cent (ACD) and 53.33 per cent (WMD) respondents have adopted the recommended practices (technical information) and in general also 56.13 per cent have adopted the recommended practices.

The diffusion of innovations is essentially a social process in which subjectively perceived information about a new idea is communicated. Thus it can be justified that majority of the farmers have created awareness among their neighbours/ friends. One of the major goals of demonstration is to get new and profitable technologies adopted by the rural community which is reflected on other farmers having obtaining technical information from the respondents who in turn adopted and diffused technical information with the help of respondents.

With respect to technological interventions namely integrated crop management (ICM) which includes integrated nutrient management (INM), Integrated pest management (IPM) practices and Integrated water management (IWM). The ICM in combination with IPM and INM practices was spread by 65.63 per cent, 60.00 per cent, 56.67 per cent and 46.67 per cent with respect to $\mathrm{HCD}, \mathrm{WMD}, \mathrm{ACD}$ and FFS respondents respectively. In case of overall response it was 56.13 per cent. INM practice alone was diffused to 53.13 per cent of HCD, 45.00 per cent each of FFS \& WMD and 43.33 per cent of ACD and 45.75 per cent in general INM practice alone was diffused whereas, IPM practice alone was diffused to 58.33 per cent of FFS, 46.88 per cent of HCD, 46.67 per cent of ACD and 43.33 per cent of WMD. The pooled data regarding IPM practice alone diffused to 49.06 per cent. The IWM practice was diffused to 66.67 per cent of WMD, 61.67 per cent of FFS, 59.38 per cent of HCD and 51.67 per cent of ACD respondents to fellow farmers and 59.91 per cent in general.

The possible reason for this type of finding might be that the other farmers who have received information from the respondents might have been convinced about the practicability and profitability of the practice especially IPM, INM, IWM and ICM.

More number of fellow farmers were found in 
partial adoption of 56.67 per cent, 53.13 per cent, 51.67 per cent and 48.33 per cent for the technologies gained from the participants of ACD, HCD, FFS and WMD respectively and the overall adoption was 52.36 per cent. Further, 40.00 per cent 36.67 per cent, 35.00 per cent and 34.38 per cent of fellow farmers were fully adopted the different technical information provided from the participants of FFS, ACD, WMD and HCD respectively. They have partially adopted the practices as they were not beneficiaries of the activities and insufficient guidance and poor acquiring of information may be the possible reasons for partial adoption of technologies.

The diffusion effect of FFS, ACD, WMD and HCD is largely debated with several studies showing little diffusion of knowledge from FFS, ACD, WMD and HCD to non FFS, ACD, WMD and HCD participants. However, practitioners argue that the reason for less diffusion through FFS, ACD, WMD and HCD where learning was centered on problem solving and innovation skills, but not about passing on simple technological messages to other farmers. In fact the information from FFS, ACD, WMD and HCD activities are often expected to diffuse and also to generate social and economic multiplier effects that deliver positive public and private benefits. The study conducted by Braun et al., (2005) suggest that information and simple practices that can be observed by non participating famers, do diffuse from FFS participants, to some extent, but not the selfconfident knowledge and skills in problemsolving required for the purposes for which FFSs seem best suited. The results are same with the results of Dilip Trivedi and Intodia (1999) and Patel and Patel (2000).

\section{References}

Arunkumar, T.D., 2004. Profile of SHGs and their contribution for livestock development in Karnataka. M.Sc. (Agri.) Thesis, Univ. Agric. Sci., Dharwad.

Biradar, B. N., 2008. A study on impact of income generating activities on sustainable rural livelihoods of kawad project beneficiaries. M. Sc. (Agri.) Thesis, Uni. of Agric. Sci., Dharwad.

Dasaratharamaiah, K., Naidu, M. C. and Jayaraju, M., 2006. Women's empowerment through DWCRA - An empirical study. Social Welfare, 52(12): 33-38.

Dilip Trivedi and Intodia, S. L., 1999. Study on effect of motivational sources and infrastructural facilities on participation by trainees in training programme. Mah. J. Ext. Edu., 20 : 95-97.

Hari, S. and Kumawat, R.C., 2006. Impact of Swarnjayanti Gram Swarojgar Yojana (SGSY) in Jhunijhuna (Rajasthan). Rural India, 69(8-9): 164-168.

Jayachandra, K. and Gurappa Naidu, 2006. Impact of dairy cooperatives on income, employment and creation of assets of marginal and small farmers- A case study. Indian Cooperative Review, 43(4): 719-724.

Kenchanagoudar, S. M., 2007. An analytical study on sampoorna grameen rozgar yojana (sgry) in gadag district of karnataka state. M. Sc. (Agri.) Thesis, Uni. of Agric. Sci., Dharwad.

Mavi, K.S., Chauhan, J.P.S. and Das, B.C., 2006. Impact of Self Employment Programme on Dairy Farming. Rural India,70(3): 47-49.

Patel, S. R. and Patel, R. B., 2000, Inspiration sources for introducing drip irrigation system. Mah. J. Ext. Edu.,13 : 25.

Puhazhendi, V. and Jayaraman, B., 2000. Increasing women's participation and employment generation among rural poor- An approach through informal groups. National bank News Review, 15(4): 55-62. 
Shashidhar, D. N., 2004. A study on influencing factors and constraints in drip irrigation by horticulture farmers of
Bijapur district. M. Sc. (Agri.) Thesis, Uni. of Agric. Sci., Dharwad.

\section{How to cite this article:}

Ashok Doddamani, C. M. Savitha and Yashashwini, M. A. 2021. Income and Employment Generating Activities and Participation Influence of Tank Management Institute Members under KCBTMP. Int.J.Curr.Microbiol.App.Sci. 10(01): 2086-2096.

doi: https://doi.org/10.20546/ijcmas.2021.1001.240 